\title{
3 The relationship between association membership and access to formal social protection
}

\author{
A cross-sector analysis of informal \\ workers in Kenya and Tanzania
}

\section{Nina Torm}

\section{Introduction and literature}

Based on survey data of informal workers gathered across the sectors of construction, trade, and transport, this chapter analyzes the extent to which informal worker associations facilitate access to formal social protection measures in Kenya and Tanzania. Drawing on the Devereux and Sabates-Wheeler (2004) framework, which is outlined in Chapter 1 of this volume, the focus in this chapter is on preventive and promotive-type social protection measures. Protective measures ${ }^{l}$ are largely left aside as they fall outside the immediate scope of what informal associations might assist with, and transformative measures are looked at in more detail in the sector-specific chapters of this book. The chapter finds inspiration in the Power Resources Approach (PRA) developed by Wright (2000) and Silver (2003) within which the notion of associational power is particularly interesting to engage with since it is derived from the formation of collective organizations of workers at various levels. ${ }^{2}$ Traditionally applied in the context of the Global North and formal workplaces, such organizations include grass-roots work groups, work councils, and shop-steward bodies as well as trade unions at the industry level (Schmalz, Ludwig \& Webster, 2018). In relation to informal workers, associational power may derive from different types of collective associations, institutions, and alliances created or engaged in by workers to advance their own interests and conditions.

For instance, in the case of transport workers in Dar es Salaam, Tanzania, Rizzo (2017) provides a detailed ethnographic account and portrays the rise and decline of a number of worker organizations over a period of almost 20 years. He shows that associations as collective attempts try to address the everyday challenges of daladala workers, such as paying the fines of those charged with traffic offences and supporting burial costs of immediate family. Thus, associations may enable their members to manage the precariousness of their employment (promotive measures) but not to challenge or reform it (through more transformative approaches). Despite the persistence of the necessity for 'agency' and 'voice' to 
bring workers together, Rizzo (ibid.) also shows the limitations and vulnerability of worker organizations to assert robust collective action. For instance, challenges arise from the bus owners being small-scale capitalists with little visible movement towards accumulation and growth due to their isolated work situation and low level of skills. In Rizzo (2011), he shows that, by reorganizing, daladala workers in Dar es Salaam created a welfare fund and additional income; yet, "from the outset there existed a structural imbalance between members" needs for support and the association's capacity to provide it" (p. 1196).

Moving to the construction sector in Dar es Salaam, Tanzania, Wells and Jason (2010) find that some of the driving forces and motivations behind the UNDP-funded formation of the umbrella organization TAICO (Tanzanian Association of Informal Construction Workers) in 2006 included the urgent need to increase opportunities for employment and income as well as attaining legal recognition, empowerment, and facilitating access to markets. Amongst some of the achievements, TAICO successfully lobbied the Tanzanian Government to reserve a share of public-sector contracts for informal groups of workers and campaigned for the greater adoption of labour-based construction technologies (ibid.). However, after the UNDP project ended, TAICO collapsed. ${ }^{3}$ In the case of Kenya's (informal) construction sector, Mitullah and Wachira (2003) find that umbrella associations, such as the National Federation of Jua Kali Associations of Kenya, which are well-placed for advocacy and policy influence on behalf of informal/small-scale enterprises, have generally performed poorly due to leadership issues. By contrast, KENASVIT has demonstrated more success in organizing and empowering street vendors and informal traders in order to improve their business through training, access to credit, dialogue with local authorities, and other relevant organizations (Mitullah, 2010). Whilst the significance of transnational networks for local struggles is demonstrated through the KENASVIT case, Mitullah (2010) emphasizes the importance of local engagement and capacity-building for sustainable organizing.

Studies of traders from other regions of the Global South also provide positive examples. For instance, focusing on informal street vendors in India, Kumar and Singh (2018) demonstrate the emergence of associational power. In particular, and in response to the growing numbers of street vendors facing harassment, confiscations, and sudden evictions since the 1990s, the National Association of Street Vendors of India (NASVI) was formed as an association of trade unions, community-based organizations, NGOs, and individual members to successfully advocate for street vendors' rights and policy changes. In the transport sector, Spooner and Mwanika (2018) look at how the Amalgamated Transport and General Workers' Union (ATGWU) in Uganda built informal transport workers' associational power through the affiliation of mass-membership associations of informal workers, notably representing minibus taxi workers and motorcycle taxi riders. This strategy of building a hybrid organization has assisted the union in bridging the divide between formal and informal workers, achieving substantial gains for informal workers, and reducing their vulnerability. 
Taken together, the studies show that informal self-employed workers, across different sectors, who have low structural power may, with varying degrees of success, create new forms of associational power that diverge from traditional trade union constellations. In addition to member numbers, associational power also depends on infrastructural resources, organizational efficiency, member participation, and internal cohesion, factors which of course vary across different association types and locations. Moreover, associations must optimize their structures so that associational action can be reconciled with the underlying structural conditions and the interests of the members (Schmalz, Ludwig \& Webster, 2018). In the current chapter, member interests/needs include different aspects of social protection as captured by preventive and promotive-type measures.

The above brief review shows that existing literature consists mostly of indepth sector-specific accounts of workers coming together to claim social protection, whilst cross-sector (and cross-country) evidence on such initiatives is scarce. Thus, this chapter provides an empirical contribution to a relatively small but growing literature, by comparing across sectors and locations, the extent to which informal worker associations are able to facilitate member access to formal social protection measures. Additional interpretations and in-depth sectorspecific discussions of the extent to which this is related to associational- or other types of power (or the lack thereof) are unwrapped further in the subsequent chapters of the book. The rest of this chapter is structured as follows: the next section briefly introduces the data and method used, along with a summary of selected informal worker characteristics. The subsequent section consists of the analysis and discussion of the main results, followed by a brief conclusion.

\section{Who are the informal workers?}

\section{Data and method}

This paper uses survey data of informal workers gathered in Tanzania and Kenya during 2018 under the collaborative Danida-funded project as described in Chapter 1. The data was collected for workers engaged in construction, trade, and transport-sectors which are all highly prone to informality. Location-wise, data was sampled from two urban areas in each country: Nairobi and Kisumu in Kenya and Dar es Salaam and Dodoma in Tanzania. In each location, three zones/districts were identified through transport hubs, and the same sites were used across the three sectors. The survey covered wage-workers, own-account workers, and micro-businesses with maximum two employees at any given point in time, thus a broad segment of informal worker types. The sampling was done so that 25 percent of workers were sampled through (registered) associations identified purposively for the project. The reasoning behind this was to ensure a broad coverage of different types of associations amongst our respondents, whilst being aware of the potential bias that this introduces to the sample. The remaining 75 percent were sampled by geography to ensure a degree of randomness, 
bearing in mind that it is not possible to ensure a representative sample when there is no clearly defined population of informal workers (and hence the probability of selection cannot be specified). This random sampling was also intended to capture members of smaller more unestablished worker associations. The initial aim was to interview 1,200 workers in total - 600 per country ( 100 workers per sector, per site); yet, due to oversampling, the total sample counted 1,462 workers, which, after a thorough cleaning process, resulted in a final sample of 1,385 observations. ${ }^{4}$

\section{Main characteristics}

Table 3.1 provides summary statistics for selected variables based on the full data sample including the 25 percent of workers that were purposively sampled through associations. In order to check whether the pattern differs for the

Table 3.1 Key summary statistics

\begin{tabular}{|c|c|c|c|c|c|c|}
\hline & \multicolumn{2}{|l|}{$A l l$} & \multicolumn{2}{|l|}{ Kenya } & \multicolumn{2}{|c|}{ Tanzania } \\
\hline & Mean & $S D$ & Mean & $S D$ & Mean & $S D$ \\
\hline Association member* & 0.41 & 0.49 & 0.48 & 0.50 & 0.34 & 0.48 \\
\hline $\begin{array}{l}\text { Formal social insurance enrolment } \\
\text { (health/pension) }\end{array}$ & 0.26 & 0.44 & 0.34 & 0.48 & 0.18 & 0.39 \\
\hline Health insurance coverage & 0.29 & 0.45 & 0.41 & 0.49 & 0.19 & 0.39 \\
\hline Nairobi & 0.26 & 0.44 & 0.57 & 0.50 & 0.00 & 0.00 \\
\hline Kisumu & 0.20 & 0.40 & 0.43 & 0.50 & 0.00 & 0.00 \\
\hline Dodoma & 0.30 & 0.46 & 0.00 & 0.00 & 0.56 & 0.50 \\
\hline Dar & 0.24 & 0.42 & 0.00 & 0.00 & 0.44 & 0.50 \\
\hline Gender $($ male $=1)$ & 0.77 & 0.42 & 0.77 & 0.42 & 0.78 & 0.42 \\
\hline Age & 35.23 & 9.89 & 36.20 & 9.80 & 34.38 & 9.89 \\
\hline Married & 0.66 & 0.47 & 0.76 & 0.43 & 0.58 & 0.49 \\
\hline Locally born & 0.37 & 0.48 & 0.26 & 0.44 & 0.46 & 0.50 \\
\hline Mean daily earnings (current USD)** & 10.54 & 14.22 & 10.74 & 9.19 & 10.36 & 17.45 \\
\hline Assets (house and/or land) & 0.35 & 0.48 & 0.27 & 0.44 & 0.43 & 0.50 \\
\hline Primary incomplete & 0.10 & 0.30 & 0.11 & 0.32 & 0.09 & 0.28 \\
\hline Primary complete & 0.53 & 0.50 & 0.42 & 0.49 & 0.62 & 0.48 \\
\hline Secondary or above & 0.37 & 0.48 & 0.47 & 0.50 & 0.29 & 0.45 \\
\hline Professional training course & 0.22 & 0.42 & 0.27 & 0.45 & 0.18 & 0.39 \\
\hline Training on job & 0.25 & 0.43 & 0.32 & 0.47 & 0.18 & 0.39 \\
\hline Self-taught & 0.53 & 0.50 & 0.41 & 0.49 & 0.64 & 0.48 \\
\hline Construction & 0.31 & 0.46 & 0.34 & 0.48 & 0.28 & 0.45 \\
\hline Trade & 0.37 & 0.48 & 0.35 & 0.48 & 0.39 & 0.49 \\
\hline Transport & 0.32 & 0.47 & 0.31 & 0.46 & 0.34 & 0.47 \\
\hline Wage-worker & 0.37 & 0.48 & 0.55 & 0.50 & 0.22 & 0.41 \\
\hline Own-account & 0.52 & 0.50 & 0.38 & 0.49 & 0.64 & 0.48 \\
\hline Micro-business & 0.11 & 0.31 & 0.07 & 0.26 & 0.14 & 0.35 \\
\hline Observations & 1,385 & & 644 & & 741 & \\
\hline
\end{tabular}

Source: Author's elaboration based on the survey data.

Notes: Summary statistics based on the full sample. * Association member figures are from the random sample consisting of 979 workers (see also Table Al). ${ }^{*}$ Median earnings are USD 7.6 for the full sample, USD 6.5 for Tanzania, and USD 8.7 for Kenya. 
75 percent of workers sampled randomly, we present the summary statistics for those in Appendix Table Al. With the obvious exception of the association member variable, there are no significant differences between the two samples. Thus, the stratification of part of the sample does not seem to impose any bias, at least in terms of the variables chosen, and I therefore proceed using the full sample in the analysis. The association member share (based on the random sample) shows that, overall, 41 percent of workers belong to some type of association with the share being higher in Kenya at 48 percent compared with 34 percent in Tanzania. ${ }^{5}$ However, the incidence of association membership varies substantially across the three sectors and by country. ${ }^{6}$

Proceeding to the other variables, Table 3.1 indicates that 26 percent of workers contribute to a formal social insurance (SI) scheme, and the share is almost double in Kenya (34 percent) compared with Tanzania (18 percent). ${ }^{7}$ Reassuringly, these figures are in accordance with the official estimates, as indicated in Chapter 2. Across both countries, the vast majority of workers referred to bealth insurance specifically; in fact, out of the 358 workers that answered positively to contributing to some type of SI, 78 percent reported health insurance, 16 percent pension fund, and 7 percent other insurance. The low pension share is not surprising, given that, in Kenya, only about 250,000 of the 14 million informal workers are registered with the National Social Security Fund ${ }^{8}$ (NSSF, 2017), with Tanzania having an even lower share, as outlined in Chapter 2. The reasons provided for not being part of any official social insurance scheme include that it is too expensive, and workers have a lack of knowledge about the schemes. ${ }^{9}$ In Kenya, for those that do contribute to health insurance, almost 80 percent of workers contribute directly to the provider and 20 percent through an association, compared with the division being 53 percent and 47 percent in Tanzania, a difference which is likely due to the group-based KIKOA scheme in Tanzania, which is explained in more detail in Chapter 2. In both countries, individual National Health Insurance Fund (NHIF) enrolment also covers immediate family members, and thus, we include health insurance coverage as a variable in Table 3.1. ${ }^{10}$ Logically, the coverage rate is higher than enrolment, at 29 percent on average and especially for Kenya at 41 percent compared with 19 percent for Tanzania. Reassuringly, these figures are consistent with the national coverage rates estimated at 39 percent in Kenya (KSPSR, 2017) and 22 percent for Tanzania (Jacob \& Pedersen, 2018b).

In terms of location, the largest share of workers is based in Dodoma followed by Nairobi, Dar, and Kisumu. The variable "local" indicates that, in Kenya, 26 percent of workers were born in the city where they work; yet, for Tanzania, the share is 46 percent, pointing to a lower incidence of internal migration in the latter, related to a higher level of urbanization in Tanzania compared to Kenya. As for gender, 77 percent of the sample are men, and the mean age is 35 years. Regarding education, 10 percent have below the primary level, whilst 53 percent have completed primary education and 37 percent have completed secondary school. In Kenya, a higher share of workers have secondary education compared with Tanzania; but, in general, workers are well-educated. In terms of training, 
the vast majority of workers are self-taught at 53 percent overall and as high as 64 percent in Tanzania compared with 41 percent in Kenya. Around 25 percent have had on-the-job training, and 22 percent have attended a professional training school, with both shares being slightly higher in Kenya. In terms of worker types, own-account represent the vast majority with 52 percent on average and as high as 64 percent in Tanzania, whereas, in Kenya, wage-workers make up the largest share with 55 percent, whilst 38 percent are own-account workers. ${ }^{11}$ Micro-businesses constitute only around 11 percent of the sample. As for the sectors, the distribution is relatively even, although with a slightly higher share of trade and transport in Tanzania and a somewhat higher share of construction in Kenya.

With regard to the mean daily earnings across all workers, this is around USD 11, only slightly higher in Kenya compared with Tanzania. ${ }^{12}$ Interestingly, in the case of Tanzania, earnings are comparable to the 2016 monthly earnings estimate reported for workers in the formal sector of TZS 448,462 (USD 196). When looking at Tanzania earnings in more detail, there seems to be some quite high figures reported, especially in construction, which is also related to the higher share of piece-rate and contractual workers, whereas, in Kenya, the most common form of payment in construction is time-rate. ${ }^{13}$ In the case of Kenya, the official monthly earnings estimate from 2017 was KES 57,008 (USD 563), so substantially above the informal earnings from the survey. Thus, the difference in official earnings data between Kenya and Tanzania does not seem to be reflected among informal workers. However, between the three sectors, there is substantial variation in earnings especially in Tanzania, where traders earn well below the formal sector average, whilst construction workers earn above, and transport workers somewhere in the middle. By contrast, in Kenya, the sectorspecific earnings distributions are more homogenous. ${ }^{14}$ Keeping in mind that informal workers are generally in a less predictable work situation compared with formal workers, this nevertheless seems to suggest that working in the informal construction sector in Tanzania may not always be a last resort option. ${ }^{15}$ The large variation in earnings among informal workers in Tanzania is shown by the SD being above the mean in Table 3.1. Thus, for accuracy, we also report the median earnings (in the note of the table) which are well below their respective means due to the right skew of the distribution, whereby the bulk of the sample are relatively low earners, with a few heavy earners at the top pulling up the mean. Due to this skewed earnings distribution in the analysis that follows, the log transformation is used, which makes the distribution appear more symmetric (more normal). Finally, 35 percent of workers own assets, with the share being substantially higher in Tanzania at 43 percent, compared with 25 percent in Kenya. This difference could be related to the finding that Tanzanian workers have a higher likelihood of working where they were born, which means that they are more likely to own property either by inheritance or having bought land (which is generally cheaper in Tanzania compared to Kenya).

Turning to Table 3.2, which displays summary statistics for association members only, in terms of social insurance enrolment, the share is 30 percent, which is 


\section{Nina Torm}

Table 3.2 Key worker characteristics, association members

\begin{tabular}{|c|c|c|c|c|c|c|}
\hline & \multicolumn{2}{|l|}{ All } & \multicolumn{2}{|c|}{ Kenya } & \multicolumn{2}{|c|}{ Tanzania } \\
\hline & Mean & $S D$ & Mean & $S D$ & Mean & $S D$ \\
\hline $\begin{array}{l}\text { Formal social insurance enrolment (health/ } \\
\text { pension) }\end{array}$ & 0.30 & 0.46 & 0.40 & 0.49 & 0.21 & 0.41 \\
\hline Health insurance coverage & 0.34 & 0.47 & 0.47 & 0.50 & 0.22 & 0.41 \\
\hline \multicolumn{7}{|l|}{ Association type } \\
\hline Sacco/vicoba/chama & 0.51 & 0.50 & 0.64 & 0.48 & 0.39 & 0.49 \\
\hline Work-related association & 0.44 & 0.50 & 0.29 & 0.45 & 0.58 & 0.49 \\
\hline Women/youth/religious & 0.05 & 0.22 & 0.07 & 0.25 & 0.04 & 0.19 \\
\hline \multicolumn{7}{|l|}{ Benefit type } \\
\hline Work-related & 0.37 & 0.48 & 0.34 & 0.47 & 0.40 & 0.49 \\
\hline Social cushioning & 0.13 & 0.33 & 0.05 & 0.21 & 0.20 & 0.40 \\
\hline Voice and representation & 0.05 & 0.21 & 0.04 & 0.20 & 0.05 & 0.22 \\
\hline Loans & 0.46 & 0.50 & 0.57 & 0.50 & 0.35 & 0.48 \\
\hline Barriers $($ yes $=1)$ & 0.64 & 0.48 & 0.62 & 0.49 & 0.66 & 0.48 \\
\hline Association fee (yes $=1)$ & 0.73 & 0.44 & 0.77 & 0.42 & 0.69 & 0.46 \\
\hline Observations & 800 & & 388 & & 412 & \\
\hline
\end{tabular}

Source: Author's elaboration based on the survey data.

higher than that for all workers (Table 3.1), and again, enrolment incidence is the double in Kenya compared with Tanzania. As expected, health insurance coverage is also higher for members at 34 percent (compared with 29 percent for all), and for Kenya, the 47 percent coverage is quite a bit above the national average. As for the various types of associations, more than 50 percent report belonging to a sacco/vicoba/chama, which is obviously a rather broad categorization that may encapsulate a variety of types of associations and services/ functions. As with social insurance enrolment, there is also substantial variation by country, in that the incidence of sacco/vicoba/chama is significantly higher in Kenya at 64 percent compared with 39 percent in Tanzania. Overall, 44 percent belong to a worker association, and here, the pattern is the opposite with a higher share in Tanzania at 58 percent compared with 29 percent in Kenya. Finally, around 5 percent of workers belong to either women or youth-specific or other types of association.

Another way of categorizing associations is to look at the different kinds of benefits that they provide, and here, 46 percent of workers report that the main benefit is the opportunity to save and receive loans, whilst 37 percent state that it is work-related. ${ }^{16}$ Another 13 percent answer that the main benefit is social cushioning, which includes access to formal health (and pension) insurance as well as informal support for children's education, funerals, weddings, etc. ${ }^{17} \mathrm{Fi}$ nally, 5 percent answer protection against harassment, eviction, or confiscation of goods, which may be interpreted as voice and representation. As for the types of associations, the distribution of variables varies somewhat by country with a 
higher than average work-related and social cushioning share in Tanzania, and a higher than average loans share in Kenya. Finally, the majority of respondents (64 percent) answer that there are barriers to enter associations and 73 percent report paying an association fee, the latter being higher in Kenya (77 percent) compared with Tanzania (69 percent). ${ }^{18}$ Such differences in terms of associations' services and access across countries and between sectors are explored further in the sector-specific chapters of this volume. ${ }^{19}$

\section{Association members versus non-members}

Since this paper looks at the extent to which association membership is associated with formal SI, it is of interest to look at any significant differences across the relevant variables when comparing members with non-members. First, as expected, Table 3.3 shows that association members are significantly more likely to be enrolled in a social insurance scheme, which, as indicated earlier, covers mostly health-related protection. In fact, 30 percent of members contribute to social insurance compared to 20 percent of non-members. When health insurance coverage is considered, the shares are 34 percent and 22 percent, respectively. As for

Table 3.3 Differences in key workers characteristics by association member status

\begin{tabular}{|c|c|c|c|c|}
\hline & Member & $\begin{array}{l}\text { Not } \\
\text { Member }\end{array}$ & Difference & $t$-Value \\
\hline $\begin{array}{l}\text { Formal social insurance enrolment } \\
\text { (health/pension) }\end{array}$ & 0.30 & 0.20 & 0.11 & 4.53 *** \\
\hline Health insurance coverage & 0.34 & 0.22 & 0.12 & 4.85 \\
\hline Nairobi & 0.26 & 0.26 & 0.00 & 0.02 \\
\hline Kisumu & 0.22 & 0.17 & 0.05 & $2.15^{* *}$ \\
\hline Dodoma & 0.30 & 0.29 & 0.01 & 0.51 \\
\hline Dar & 0.21 & 0.27 & -0.06 & $-2.61^{* *}$ \\
\hline Gender $($ male $=1)$ & 0.72 & 0.84 & -0.12 & $-5.19 * * *$ \\
\hline Married & 0.72 & 0.59 & 0.12 & $4.83^{* * *}$ \\
\hline Local & 0.39 & 0.35 & 0.04 & 1.48 \\
\hline Age & 36.56 & 33.40 & 3.16 & $5.95 * * *$ \\
\hline Mean daily earnings (current USD)* & 10.84 & 10.48 & 0.36 & 0.46 \\
\hline Assets (house and/or land) & 0.38 & 0.32 & 0.06 & $2.21^{* *}$ \\
\hline Primary incomplete & 0.09 & 0.11 & -0.02 & -1.30 \\
\hline Primary complete & 0.54 & 0.51 & 0.03 & 1.26 \\
\hline Secondary or above & 0.37 & 0.38 & -0.01 & -0.50 \\
\hline Training course & 0.25 & 0.19 & 0.05 & $2.21^{* *}$ \\
\hline Training on job & 0.23 & 0.26 & -0.03 & -1.31 \\
\hline Self-taught & 0.52 & 0.54 & -0.02 & -0.71 \\
\hline Construction & 0.24 & 0.40 & -0.17 & $-6.71 * * *$ \\
\hline Trade & 0.38 & 0.35 & 0.02 & 0.90 \\
\hline Transport & 0.39 & 0.24 & 0.14 & $5.64 * * *$ \\
\hline Wage-worker & 0.34 & 0.42 & -0.08 & $-3.15^{* * *}$ \\
\hline Own-account & 0.53 & 0.51 & 0.02 & 0.62 \\
\hline Micro-business & 0.14 & 0.07 & 0.06 & $3.82 * * *$ \\
\hline Observations & 1,385 & & & \\
\hline
\end{tabular}

Source: Author's elaboration based on the survey data. 
locations, Kisumu workers are more likely to be association members, whereas, in Dar, workers are more likely not to be members. There is a higher share of men amongst non-members than among members, which matches the fact that construction workers are significantly more likely to be non-members. ${ }^{20}$ By contrast, in the transport sector, workers are more likely to be association members, whereas, in trade, there is no significant difference. Association members are older, more likely to be married and have assets, and they are also more likely to have attended a professional training course, but, otherwise, educational background does not differ by membership. Finally, micro-businesses are more likely to be association members and the opposite for wage-workers, whilst for ownaccount workers - the vast majority - the distribution is more or less equal.

Table 3.3 reveals that earnings do not differ significantly between members and non-members; yet, interestingly, when looking only at Kenya, association members have higher average incomes than non-members, whereas, in Tanzania, the opposite is the case. ${ }^{21}$ Recalling from Table 3.2 that Kenyan workers have a relatively higher membership share in associations where receiving loans is reported as the main benefit, it is perhaps not surprising that these workers, on average, have higher earnings than non-association members. On the other hand, Tanzanian workers have a higher share of members in worker associations that report social cushioning and work-related benefits as being the most important. Following on, from this, I turn to look at what distinguishes workers that are enrolled in formal protection schemes from those that are not.

\section{Social insurance enrolment persus non-enrolment}

In Table 3.3, we saw that there was a relation between being association member and contributing to formal SI, and this is supported by Table 3.4 which shows that 68 percent of those enrolled in formal SI are also association members, whereas members constitute a lower share of those that are not enrolled ( 54 percent). ${ }^{22}$ In terms of the types of associations, there is a significantly higher share of those workers in SI enrolment that are sacco/vicoba/chama members compared with those that are not enrolled. Correspondingly, enrolled workers are more likely to be receiving loans from their associations, possess assets, and have higher earnings compared with those not enrolled. SI receivers are older than non-receivers, and they are also more likely to be married. Nairobi has the largest share of workers enrolled in formal SI schemes, whereas Dar es Salaam has a higher proportion of non-enrolled workers, compared to Dodoma which has a relatively high share of enrolled workers, likely due to the community health fund scheme. In terms of education, those enrolled are significantly better educated, and non-enrollers are more likely to be self-taught. As for the sectors, only transport workers differ by being more represented amongst those enrolled and the same for wage-workers and micro-businesses, whilst own-account workers have a higher likelihood of not contributing to SI. Having uncovered significant differences by association membership status and SI enrolment along a variety of worker characteristics, we now turn to examining the extent to which being 
Table 3.4 Differences in key workers characteristics by social insurance enrolment

\begin{tabular}{|c|c|c|c|c|}
\hline & $\begin{array}{l}\text { Social } \\
\text { Insurance }\end{array}$ & $\begin{array}{l}\text { No Social } \\
\text { Insurance }\end{array}$ & Difference & t-Value \\
\hline Association member & 0.68 & 0.54 & 0.14 & $4.53 * * *$ \\
\hline Sacco/vicoba/chama & 0.40 & 0.26 & 0.14 & $5.20 * * *$ \\
\hline Work-related association & 0.24 & 0.26 & -0.02 & -0.59 \\
\hline Women/youth/religious & 0.04 & 0.03 & 0.01 & 0.77 \\
\hline Work-related & 0.24 & 0.21 & 0.03 & 1.27 \\
\hline Loans & 0.35 & 0.23 & 0.12 & $4.54 * * *$ \\
\hline Voice and representation & 0.03 & 0.03 & 0.00 & 0.17 \\
\hline Social cushioning & 0.06 & 0.08 & -0.02 & -1.03 \\
\hline Nairobi & 0.37 & 0.22 & 0.15 & $5.58 * * *$ \\
\hline Kisumu & 0.25 & 0.19 & 0.06 & $2.43^{* *}$ \\
\hline Dodoma & 0.28 & 0.31 & -0.03 & -0.97 \\
\hline Dar & 0.10 & 0.28 & -0.18 & -7.10 *** \\
\hline Gender $($ male $=1)$ & 0.78 & 0.77 & 0.01 & 0.32 \\
\hline Married & 0.79 & 0.62 & 0.17 & $6.08 * * *$ \\
\hline Local & 0.38 & 0.37 & 0.01 & 0.27 \\
\hline Age & 37.05 & 34.59 & 2.46 & $4.08 * * *$ \\
\hline $\begin{array}{l}\text { Mean daily earnings (current } \\
\text { USD) }\end{array}$ & 12.77 & 9.96 & 2.80 & $3.19 * * *$ \\
\hline Assets (house and/or land) & 0.40 & 0.34 & 0.06 & $1.94^{*}$ \\
\hline Primary incomplete & 0.06 & 0.11 & -0.05 & $-2.97 * *$ \\
\hline Primary complete & 0.44 & 0.56 & -0.11 & $-3.76^{* \star *}$ \\
\hline Secondary or above & 0.50 & 0.33 & 0.17 & $5.76^{* * *}$ \\
\hline Training course & 0.32 & 0.19 & 0.12 & $4.88^{* * *}$ \\
\hline Training on job & 0.25 & 0.24 & 0.00 & 0.16 \\
\hline Self-taught & 0.44 & 0.56 & -0.13 & -4.20 *** \\
\hline Construction & 0.29 & 0.31 & -0.03 & -0.95 \\
\hline Trade & 0.33 & 0.38 & -0.05 & -1.73 \\
\hline Transport & 0.38 & 0.30 & 0.08 & $2.72 * *$ \\
\hline Wage-worker & 0.44 & 0.35 & 0.09 & $3.08 * * *$ \\
\hline Own-account & 0.41 & 0.56 & -0.15 & $-5.06^{* * *}$ \\
\hline Micro-business & 0.16 & 0.09 & 0.06 & $3.35^{* * *}$ \\
\hline Observations & 1,385 & & & \\
\hline
\end{tabular}

Source: Author's elaboration based on the survey data.

member of an informal worker association is related to participation in a formal social insurance scheme.

\section{Association membership, earnings, and access to formal social security}

In order to examine the correlation between being member of an informal worker association and access to formal SI, I use a standard probit model, where SI is the outcome (dependent) variable taking a binary form and the same for the main variable of interest which is association membership. ${ }^{23}$ Table 3.5 column 1 reports the correlation between association membership and contributing to SI when key worker characteristics are controlled for. The results show that members are 27 percent more likely to contribute to SI compared with non-members, 
Table 3.5 Association membership and formal social insurance

(1)

(2)

(3)

\begin{tabular}{llll}
\hline Member & $0.265^{* * *}(0.080)$ & $0.198^{* *}(0.083)$ & \\
Male & $-0.105(0.098)$ & $-0.049(0.120)$ & $-0.029(0.122)$ \\
Age & $-0.010(0.024)$ & $-0.001(0.024)$ & $-0.000(0.024)$ \\
Age`2 & $0.021(0.029)$ & $0.012(0.030)$ & $0.011(0.030)$ \\
Married & $0.357^{* * *}(0.090)$ & $0.295^{* * *}(0.093)$ & $0.307^{* * *}(0.093)$ \\
Assets & $0.018(0.080)$ & $0.108(0.084)$ & $0.111(0.084)$ \\
Local & $0.113(0.079)$ & $0.145^{*}(0.086)$ & $0.153^{*}(0.087)$ \\
Secondary education+ & $0.426^{* * *}(0.121)$ & $0.471^{* * *}(0.123)$ & $0.471^{* * *}(0.123)$ \\
Training course & $0.168(0.105)$ & $0.095(0.110)$ & $0.096(0.110)$ \\
Training on job & $0.036(0.097)$ & $-0.009(0.103)$ & $-0.009(0.103)$ \\
Mean daily earnings & $0.076^{*}(0.046)$ & $0.056(0.048)$ & $0.055(0.048)$ \\
$\quad$ (USD) & & & \\
Micro-business & $0.318^{* * *}(0.122)$ & $0.372^{* * *}(0.126)$ & $0.386^{* * *}(0.126)$ \\
Wage-worker & $0.274^{* * *}(0.089)$ & $0.214^{* *}(0.106)$ & $0.240^{* *}(0.107)$ \\
Nairobi & & $0.801^{* * *}(0.125)$ & $0.747^{* * *}(0.128)$ \\
Kisumu & & $0.546^{* * *}(0.131)$ & $0.498^{* * *}(0.134)$ \\
Dodoma & & $0.444^{* * *}(0.123)$ & $0.435^{* * *}(0.124)$ \\
Trade & & $0.189(0.137)$ & $0.177(0.138)$ \\
Transport & & $0.307^{* * *}(0.105)$ & $0.314^{* * *}(0.105)$ \\
Work-related & & & $0.156(0.105)$ \\
Social cushioning & & & $-0.013(0.161)$ \\
Voice and representation & & 1,385 & $0.059(0.241)$ \\
Loans & & & $0.318^{* * *}(0.099)$ \\
N & 1,385 & & 1,385 \\
\hline
\end{tabular}

Source: Author's elaboration based on the survey data.

Notes: Marginal effects for the probit estimations. Dep. variable: worker contributes to formal health/social insurance. Robust standard errors in parentheses. ${ }^{*} \mathrm{p}<0.10,{ }^{*} \mathrm{p}<0.05,{ }^{* *} \mathrm{p}<0.01$.

ceteris paribus. In column 2, location and sector dummies are added which reduces the likelihood of association members participating in SI to 20 percent. In terms of the various control variables, I note that married and more educated workers that are classified as wage-workers or micro-businesses in the transport sector (as compared with construction and micro-trade) are more likely to contribute to SI. The reason that transport workers are significantly more likely to participate in SI is due to the specific set-up for informal transport workers in Kenya, whereby matatu workers are legally required to belong to a Sacco/transport management company, and these may commission certain savings to pay for the workers' NHIF (and NSSF) coverage. In terms of location, workers in Nairobi, Kisumu, or Dodoma have a higher chance of being part of a formal SI scheme compared with those based in Dar. Across locations, individuals that are working in the city in which they were also born have a higher chance of formal SI enrolment which is probably related to them having more knowledge of different schemes. The significance of the earnings variable in column 1 disappears when the location and sector dummies are added in column 2, indicating that earnings vary by location and/or sector, as discussed previously. ${ }^{24}$ 
In column 3, the membership variable is split into different types of associations as proxied by the key benefits they provide, revealing that the loan-type associations (whether saccos/vicobas/chamas or other informal groups) are driving the results. ${ }^{25}$ Since one of the key functions of Saccos is loan provision either directly or indirectly via establishing agreements with banks, one interpretation could be that members use the loans to pay for SI contributions. Yet, that would suggest that SI participation is also determined by earnings or assets, which Table 3.5 shows is not the case as neither determine SI participation when other factors are taken into account. The variable for social cushioning-type associations is not well-determined; yet, the negative sign indicates that workers already receiving social support (preventative social protection measures) from their associations are less likely to be in a formal SI scheme, as would be expected. ${ }^{26}$ Members of loan-type associations (promotive social protection measures) are substantially (around 32 percent) more likely to have access to SI compared with non-members. Hence, these kinds of associations are likely to serve a dual purpose of (a) ensuring some sort of financial cushioning for their members and (b) facilitating access to public insurance schemes. In relation to (a), one might then expect to find a correlation between association membership and earnings, which I examine further on, whilst (b) seems to be the result of a particular type of associational setup or purpose, potentially suggesting the presence of a degree of 'associational power'.

For instance, many of the bodaboda workers in Kenya belong to self-governed motorcycle associations like the Bodaboda Association of Kenya (BAK) which is characterized by strong associational power and works to further workers interests:

Many members have NHIF at individual level as compared to NSSF. BAK is working to have the members make contribution daily so that they cater for hospital bills, funeral expenses and in case of accident to the rider, the family members can continue earning something. There are plans to link members to insurance schemes. There is already an insurance agency in place.

(KII, Nairobi)

As for micro-traders, the data reveal that around half of the workers have come to know about the NHIF scheme from their social network, including their associations (mostly chamas), and some of these play a crucial role in terms of registering members with the NHIF:

...All members of my group are registered for NHIF and are contributing KES 200 every month through the group. Every week, the group takes a sum of KES 7000 to the NHIF. If a member is unable to pay the KES 200 the group takes the money from the members' savings and pays for him or her. The member who is being paid for is considered to have a debt of the group which he or she must pay.

(FGD, Kisumu) 
Thus, in addition to facilitating enrolment, this particular group also prevents default among their members, although this is not common practice and generally SI payments are made individually. In the case of construction, where participation in formal social insurance schemes is less common, an association member in Kenya points out:

People are different. Not all members of the group have NHIF. There are those that are being pushed to have insurance. We live from hand to mouth and it also makes it hard for us to pay the NHIF.

(FGD, Nairobi)

For the particular association referred to here, members have NHIF on an individual basis (or as a family), and the members mentioned that it is very difficult to have insurance as a group. However, the association is encouraging members to have NHIF.

In Tanzania, the link between membership and formal SI relates partly to the "KIKOA" scheme which under the NHIF Mutual Plan provided health packages tailored to groups of informal workers with 20 or more members. Due to the relatively affordable premium, different types of worker associations (including saccos, vicobas, bodaboda, and daladala group) were motivated to register, in turn, receiving SI for their members. The scheme began in 2015, yet was terminated at the end of 2019 due to issues of adverse selection (see Chapter 2 in this volume for more detail).

In combination with the survey data, such insights explain the observed positive relation between membership and SI, whilst pointing to sector (and location)specific differences which are explored further in the other chapters of the book.

Turning to the earnings analysis, Table 3.6 presents the OLS results when the dependent variable is the log of mean earnings (in USD), and again, our main variable of interest is association membership. Following a standard Mincer earnings function (Mincer, 1974), we control for education and training of the worker and use worker age as a proxy for experience. ${ }^{27}$ In addition, we add job function, sector, and location as these are also expected to account for some of the variation in earnings. In column 1 , when worker-specific controls are included, association members have earnings that are 12 percent higher compared with non-members, and in column 2, when location and sector dummies are added, they fall slightly to 11.6 percent. As for the controls, men earn between 36 percent and 49 percent more than women, which is higher than in much of the gender pay gap literature. ${ }^{28}$ Earnings increase with age (albeit at a diminishing rate) and assets, whereas workers living in the city they were born have lower earnings. In line with the literature, workers that have a post-secondary education and have undergone training have higher earnings (see Bjerge, Torm \& Trifković, 2021). Wage-workers earn substantially below own-account workers, who, in turn, earn less than micro-businesses, and workers in Kenya have higher earnings compared with Dar, whilst Dodoma is at the bottom.

As for the different sectors, transport workers earn more than microtraders; yet, construction workers are the highest earners on average (especially 
Table 3.6 Association membership and earnings

(1)

(2)

(3)

\begin{tabular}{lccc}
\hline Member & $0.125^{* * *}(0.047)$ & $0.116^{* *}(0.046)$ & \\
Male & $0.485^{* * *}(0.066)$ & $0.355^{* * *}(0.074)$ & $0.358^{* * *}(0.074)$ \\
Age & $0.059^{* * *}(0.015)$ & $0.048^{* * *}(0.014)$ & $0.048^{* * *}(0.014)$ \\
Age 2 & $-0.075^{* * *}(0.019)$ & $-0.064^{* * *}(0.018)$ & $-0.064^{* * *}(0.018)$ \\
Married & $0.055(0.055)$ & $0.004(0.055)$ & $0.005(0.055)$ \\
Assets & $0.058(0.049)$ & $0.114^{* *}(0.050)$ & $0.115^{* *}(0.050)$ \\
Local & $-0.193^{* * *}(0.049)$ & $-0.107^{* *}(0.053)$ & $-0.106^{* *}(0.053)$ \\
Secondary education+ & $0.293^{* * *}(0.074)$ & $0.256^{* * *}(0.075)$ & $0.256^{* * *}(0.075)$ \\
Training course & $0.275^{* * *}(0.068)$ & $0.183^{* * *}(0.071)$ & $0.183^{* * *}(0.071)$ \\
Training on job & $0.244^{* * *}(0.059)$ & $0.124^{* *}(0.060)$ & $0.125^{* *}(0.060)$ \\
Micro-firm & $0.215^{* *}(0.086)$ & $0.231^{* * *}(0.084)$ & $0.233^{* * *}(0.085)$ \\
Wage-worker & $-0.169^{* * *}(0.052)$ & $-0.403^{* * *}(0.057)$ & $-0.399^{* * *}(0.058)$ \\
Nairobi & & $0.309^{* * *}(0.065)$ & $0.302^{* * *}(0.066)$ \\
Kisumu & & $0.260^{* * *}(0.075)$ & $0.251^{* * *}(0.075)$ \\
Dodoma & & $-0.135^{*}(0.070)$ & $-0.139^{* *}(0.070)$ \\
Construction & & $0.129^{* *}(0.054)$ & $0.128^{* *}(0.054)$ \\
Trade & & $-0.301^{* * *}(0.071)$ & $-0.305^{* * *}(0.071)$ \\
Work-related & & & $0.093(0.058)$ \\
Social cushioning & & & $0.113(0.080)$ \\
Voice and representation & & & $0.103(0.143)$ \\
Loans & & $0.753^{* * *}(0.279)$ & $0.755^{* * *}(0.279)$ \\
Constant & $0.329(0.284)$ & 1,385 \\
N & 1,385 & 1,385 & \\
\hline Source Aun & & & \\
\hline
\end{tabular}

Source: Author's elaboration based on the survey data.

Notes: Marginal effects for the OLS estimations. Dep. variable: worker earnings (log mean in USD). Robust standard errors in parentheses. ${ }^{*} \mathrm{p}<0.10,{ }^{* *} \mathrm{p}<0.05,{ }^{* * *} \mathrm{p}<0.01$.

in Tanzania). In column 3 , the association membership variable is again split into the association/benefit types revealing that the membership "effect" is driven by workers in loan-type associations. This indeed suggests that one mechanism through which loan-type associations enable their members' access to public insurance schemes is through the provision of loans. However, it might also be that high earning workers chose to be association members and are able to pay for social insurance regardless of membership, using the loans for expanding their business, etc. (in turn, leading to even higher earnings). In addition to loans, work-related benefit-type associations are close to being well-determined and associated with higher earnings, which is not surprising given that this category includes a more secure job contract and higher or more stable income, etc.

The general finding that members earn more than non-members is supported by one of the KII from the transport sector in Kenya, which reveals that Sacco members, in this case, earn more than workers in the formal sector:

We want the boda-boda job to be respected as we have seen that even the kind of money we get is even more than that of those in formal employment, 
some of our members are getting more than even teachers in the government employment.

(KII, Kisumu)

When splitting by country, differences across the two countries are revealed in terms of the kinds of workers associations attract and what workers use their associations for. For instance, in Kenya, associations mostly facilitate access to formal systems of health insurance (preventive measures) and play a promotive role such as providing micro-credit/loans, as also discussed in other chapters of the book. By contrast, in Tanzania, workers seem to use associations more as cushioning mechanisms and for other more transformative types of social protection protection (e.g. voice and representation).

In the survey, earnings are reported as current and so is membership status; thus, there is a possibility that the observed positive relation between association membership and earnings is driven by reverse causality if high earners self-select into associations rather than higher earnings being an outcome of membership. This possibility is investigated further in Torm (2020), and the preliminary findings indicate that earnings are indeed an outcome of association membership and not vice versa.

To sum up, the results show that association members, in particular, those that are members of loan-type associations are substantially more likely to be enrolled in formal SI schemes. Second, and relatedly, association members have earnings that are significantly higher than non-members, when other relevant factors are controlled for. These findings hold in general, yet the underlying mechanism through which social protection coverage occurs via associations differs by sector and country, as does the extent to which this is explained by associational power or other types of power resources. These relations are explored further in other chapters of this edited book.

\section{Conclusion}

Against the background of an increasing global drive towards universal social protection, this paper has set out to analyze the extent to which informal workers, through association membership, are able to access formal social protection schemes in urban areas of Kenya and Tanzania. In both countries, existing formal SI schemes are open to informal workers, yet uptake is generally limited due to various factors including lack of information and limited efforts in reaching out to informal workers. In this context, informal worker associations, in a variety of constellations, may act to bridge the divide, in addition to potentially providing direct social support to their members. For instance, initiatives like saving clubs and representation of members towards authorities and/or employers also fall within the broader conceptualization of social protection, acknowledging the fact that informal worker associations often are engaged in numerous activities.

In order to understand the motivations behind workers coming together in associations, this chapter draws on the PRA, the premise of which is that organized 
labour can successfully defend its interests by collective mobilization of power, be it structural, associational, symbolic, logistical, or institutional power. In the current chapter, associational power provides a particularly interesting analytical concept as it emerges from different types of collective organizations, institutions, and alliances created or engaged in by informal workers to advance their own interests and conditions. In fact, work from across the Global South has shown that informal workers have, in some cases, been quite successful in creating new forms of associational power, which diverge from traditional power constellations.

Whereas previous studies mostly consist of sector-specific in-depth cases void of a comparative aspect, the current contribution makes use of cross-sectoral survey data from four urban locations in Kenya and Tanzania, thus adding new insight on informal workers and the outcomes of associational belonging. The results reveal that association members are significantly more likely to access formal social insurance, controlling for key worker characteristics. Moreover, across sectors and sites, the provision of loans appears to be the main direct mechanism through which this occurs. In addition, the analysis reveals a substantial earningsgap between association members and non-members, and this gap seems to vary substantially from Kenya to Tanzania. This suggests that workers may use associations for different purposes ranging from basic welfare cushioning to preventive, promotive, and/or more transformative types of social protection, which is discussed further in the other chapters of the book. Overall, the findings suggest a potentially important role for informal worker initiatives both in terms of providing direct social cushioning and indirectly through enabling participation in existing SI schemes. 


\section{Appendix A}

Table A1 Summary statistics, random sample

\begin{tabular}{|c|c|c|c|c|c|c|}
\hline & \multicolumn{2}{|l|}{ All } & \multicolumn{2}{|l|}{ Kenya } & \multicolumn{2}{|c|}{ Tanzania } \\
\hline & Mean & $S D$ & Mean & $S D$ & Mean & $S D$ \\
\hline Member & 0.41 & 0.49 & 0.48 & 0.50 & 0.34 & 0.48 \\
\hline $\begin{array}{l}\text { Social protection } \\
\text { enrolment }\end{array}$ & 0.24 & 0.43 & 0.31 & 0.46 & 0.17 & 0.38 \\
\hline $\begin{array}{l}\text { Health insurance } \\
\text { coverage }\end{array}$ & 0.26 & 0.44 & 0.37 & 0.48 & 0.16 & 0.37 \\
\hline Nairobi & 0.28 & 0.45 & 0.57 & 0.49 & 0.00 & 0.00 \\
\hline Kisumu & 0.21 & 0.41 & 0.43 & 0.49 & 0.00 & 0.00 \\
\hline Dodoma & 0.26 & 0.44 & 0.00 & 0.00 & 0.52 & 0.50 \\
\hline Dar & 0.24 & 0.43 & 0.00 & 0.00 & 0.48 & 0.50 \\
\hline $\begin{array}{l}\text { Gender (male } \\
\quad=1 \text { ) }\end{array}$ & 0.80 & 0.40 & 0.78 & 0.42 & 0.82 & 0.38 \\
\hline Age & 34.02 & 9.72 & 35.24 & 10.07 & 32.81 & 9.23 \\
\hline Married & 0.64 & 0.48 & 0.73 & 0.45 & 0.55 & 0.50 \\
\hline Local & 0.36 & 0.48 & 0.25 & 0.43 & 0.46 & 0.50 \\
\hline $\begin{array}{c}\text { Mean daily } \\
\text { earnings } \\
\text { (USD) }\end{array}$ & 10.36 & 14.15 & 10.18 & 8.44 & 10.53 & 18.10 \\
\hline Assets & 0.33 & 0.47 & 0.27 & 0.44 & 0.39 & 0.49 \\
\hline $\begin{array}{l}\text { Primary } \\
\text { incomplete }\end{array}$ & 0.10 & 0.30 & 0.11 & 0.31 & 0.09 & 0.29 \\
\hline Primary complete & 0.52 & 0.50 & 0.41 & 0.49 & 0.62 & 0.49 \\
\hline $\begin{array}{l}\text { Secondary or } \\
\text { above }\end{array}$ & 0.38 & 0.49 & 0.48 & 0.50 & 0.29 & 0.45 \\
\hline Training course & 0.21 & 0.41 & 0.26 & 0.44 & 0.16 & 0.37 \\
\hline Training on job & 0.24 & 0.43 & 0.30 & 0.46 & 0.18 & 0.39 \\
\hline Self-taught & 0.55 & 0.50 & 0.44 & 0.50 & 0.66 & 0.48 \\
\hline Construction & 0.33 & 0.47 & 0.35 & 0.48 & 0.31 & 0.46 \\
\hline Trade & 0.35 & 0.48 & 0.34 & 0.47 & 0.36 & 0.48 \\
\hline Transport & 0.32 & 0.47 & 0.31 & 0.46 & 0.33 & 0.47 \\
\hline Wage-worker & 0.40 & 0.49 & 0.56 & 0.50 & 0.25 & 0.44 \\
\hline Own-account & 0.50 & 0.50 & 0.39 & 0.49 & 0.62 & 0.49 \\
\hline Micro-business & 0.09 & 0.29 & 0.05 & 0.23 & 0.13 & 0.34 \\
\hline Observations & 979 & & 486 & & 493 & \\
\hline
\end{tabular}


Table A2 Summary statistics, association members only, random sample

\begin{tabular}{|c|c|c|c|c|c|c|}
\hline & \multicolumn{2}{|l|}{$A l l$} & \multicolumn{2}{|c|}{ Kenya } & \multicolumn{2}{|c|}{ Tanzania } \\
\hline & Mean & $S D$ & Mean & $S D$ & Mean & $S D$ \\
\hline $\begin{array}{l}\text { Social } \\
\text { protection } \\
\text { enrolment }\end{array}$ & 0.30 & 0.46 & 0.37 & 0.49 & 0.20 & 0.40 \\
\hline $\begin{array}{l}\text { Health } \\
\text { insurance } \\
\text { coverage }\end{array}$ & 0.32 & 0.47 & 0.42 & 0.49 & 0.18 & 0.39 \\
\hline $\begin{array}{l}\text { Sacco/vicoba/ } \\
\text { chama }\end{array}$ & 0.63 & 0.48 & 0.80 & 0.40 & 0.41 & 0.49 \\
\hline $\begin{array}{l}\text { Work-related } \\
\text { association }\end{array}$ & 0.29 & 0.46 & 0.13 & 0.33 & 0.52 & 0.50 \\
\hline Other & 0.07 & 0.26 & 0.08 & 0.27 & 0.06 & 0.25 \\
\hline Work-related & 0.33 & 0.47 & 0.30 & 0.46 & 0.38 & 0.49 \\
\hline $\begin{array}{l}\text { Social } \\
\quad \text { cushioning }\end{array}$ & 0.12 & 0.33 & 0.03 & 0.17 & 0.25 & 0.44 \\
\hline $\begin{array}{l}\text { Voice and } \\
\text { representation }\end{array}$ & 0.03 & 0.18 & 0.04 & 0.19 & 0.03 & 0.17 \\
\hline Loans & 0.51 & 0.50 & 0.63 & 0.48 & 0.34 & 0.48 \\
\hline $\begin{array}{l}\text { Barriers (yes } \\
\quad=1 \text { ) }\end{array}$ & 0.56 & 0.50 & 0.51 & 0.50 & 0.61 & 0.49 \\
\hline $\begin{array}{l}\text { Association fee } \\
\quad(\text { yes }=1)\end{array}$ & 0.68 & 0.47 & 0.70 & 0.46 & 0.66 & 0.47 \\
\hline Observations & 405 & & 235 & & 170 & \\
\hline
\end{tabular}




\section{Appendix B}

a Sampling method

Throughout the book, I adopt a broad definition of informal employment, including own-account/self-employment in informal enterprises (i.e. unregistered micro-business) as well as wage employment in informal jobs (i.e. without a written contract but possibly working for a formally registered enterprise). The broader term "informal economy", which also encompasses agricultural employment (not covered in this volume), was endorsed by the International Labour Conference (ILC) in 2002 (ILO, 2002; Chen, 2005) and is now commonly used instead of the older and narrower concept of the informal sector. In accordance with this broader definition of the informal economy, the survey targeted wage-workers, own-account workers, and micro-business owners with a maximum of two employees. For wage employment in informal jobs and in relation to contracts, I asked potential interviews to specify first whether they had a contract, if so whether it specifies pay and entitlement to benefits, and if so whether the details of the contract are implemented in practice. If the answer to the first two were yes, but the answer to the last one was no, I proceed with the interview on the basis of this being an informal worker.

In terms of the sectors, first, for transport, the aim was to divide the sub-sample equally between bodaboda and daladala/matatu and to sample both drivers and conductors and riders. For micro-traders, the target group were traders that were mobile (on the street, at bus terminals, vacant lots, etc.) and also less mobile ones, for example, mama lishe, but excluding those with permanent structures such as kiosks or regular designated markets. In addition, the enumerators were instructed not to over cover some commodities but rather to mix different types of traders, different types of commodities without distinguishing between what workers sold. For construction, the target groups were skilled and unskilled workers (wage-workers and own-account) employed directly by construction/ site managers or indirectly via an intermediary, for example, gang-leaders. As for the construction sites, I covered large and medium construction/building sites, waiting sites, for example, streets, buildings, and excluded individual residential housing sites.

The aim was to cover 1,200 workers in total ( 600 per country) 200 workers per sector (100 per sector per site), where 25 percent were sampled through 
associations and 75 percent by geography. For those workers sampled from associations, the target group were ordinary members and not leaders or members in an official position. Associations covered formal associations/SAC$\mathrm{COs} /$ trade unions (i.e. registered associations). For the geographical/random part of the sample, in each country, two urban locations were selected (Kenya: Nairobi and Kisumu; Tanzania: Dar es Salaam and Dodoma) and three zones/ districts per site were identified through transport hubs. The same sites were used across the three sectors. In Tanzania, the construction sector sampling was also partly based on snowballing techniques in order to identify large and medium construction/building sites. The data gathering began in June 2018, and in the first phase, 75 percent of the targeted workers were surveyed (by geography) using the Survey-to-Go software hosted by the Institute for Development Studies (IDS) of the University of Nairobi. Subsequently, information on associations that informal sector workers belonged to was obtained and extracted in preparation for the second survey data collection phase which was undertaken in November and December 2018. This phase targeted 25 percent of workers drawn from the associations covered in phase one of data collection.

\section{b Cleaning the data}

After merging the two datasets from Kenya and Tanzania, I had a total sample of 1,462 workers, yet were left with a final sample of 1,385 observations after a couple of cleaning steps as listed below:

i Removing workers that were not in the target group, including tuk-tuk drivers and bicycles;

ii Dropping workers that did not provide earnings or provided earnings above the 99th and below the 1st percentile (outliers) by country and sector;

iii Dropping workers that indicated association contributions above the 99th and below the first percentile (outliers) by country and sector.

\section{Notes}

1 Protective measures in the form of cash transfers are usually state-level interventions. See, for instance, Jacob and Pedersen (2018a) for a case study of productive social safety nets in the case of Tanzania. For Kenya, the NSPP (2011) provides a summary of formal social assistance programmes going back to 2010. Moreover, Hickey and Seekings (2017) provide a historical and conceptual account of the promotion of cash transfers in Sub-Saharan Africa, in general.

2 See Chapter 1 for a detailed description of the PRA.

3 Talks of TAICO becoming a member of the official Tanzania Mines and Construction Workers Union (TAMICO) stalled for a number of reasons including TAMICO's reluctance to welcoming members with irregular incomes and changing employers (Wells \& Jason, 2010).

4 For further detail on the sampling strategy and cleaning procedure, refer to Appendix B.

5 The full sample obviously has a higher membership share with 58 percent overall and 60 percent/56 percent for Kenya and Tanzania, respectively. 
6 In Kenya, the association membership share is 33 percent, 47 percent, and 57 percent for construction, trade, and transport, respectively, and for Tanzania, the equivalent figures are 19 percent, 34 percent, and 50 percent.

7 The question asked was "Do you contribute to an insurance scheme, for example, NHIF, national pension fund, or another insurance?"

8 NSSF presentation by Nancy Mwangi on 'practical perspective of the NSSF scheme' (Nairobi, 2017).

9 In Tanzania, out of the 80 percent that do not contribute any official social insurance scheme, 24 percent say it is too expensive; 23 percent say they have no knowledge about insurance and 12 percent say that they have no time/were never given NHIF registration. In Kenya, the major reason is that it is too expensive reported by 30 percent followed by 9 percent saying that they have no time/were never given NHIF registration. Hence, a lack of knowledge about insurance schemes is more pre-dominant in Tanzania than in Kenya. Across the countries, of the 74 percent that do not contribute around half are association members. Out of those workers that contribute, in terms of health insurance specifically, 38 percent in Kenya indicate that they receive this from a public insurance scheme, whilst 21 percent get it from a private provider. In Tanzania, the vast majority (66 percent) get it from a public insurance scheme, whilst 6 percent get it from a private provider.

10 Coverage is defined as when either the worker him/herself, the spouse, children, or another relative is the primary NHIF contributor. In the vast majority of cases and across both countries, the contribution comes mostly from the worker him/herself.

11 This discrepancy between the two countries relates partly to the groupings of especially construction workers which more often have been classified as wage-workers in Kenya and own-account workers in Tanzania (the latter is in line with the Tanzanian 2000/2001 Integrated Labor Force Survey (ILFS) where 60 percent of construction workers in Tanzania are self-employed).

12 Daily earnings are converted into the sample median of six days a week and 11 hours per day. Reported working hours are slightly longer in Tanzania than Kenya. Throughout the chapter, the average USD rate from June 2018 to December 2018 is used (101.2 for Kenya and 2,284.5 for Tanzania, per USD).

13 According to the Tanzania ILFS (NBS, 2014), (formal) workers in the construction and transport sector earn around 320,000 TZS monthly (USD 140).

14 Interestingly, in Kenya, construction is the sector with the lowest earnings and trade the highest, whilst it is the reverse in Tanzania. In relation to construction, this can be explained by the fact that the Tanzania sample includes more masons, who are ranked higher compared with the helpers (wage workers hired by the masons) who constituted the majority of the Kenya construction sample.

15 This is also supported by 19 percent of Tanzania workers responding "money being good" to the question of why they chose their job whilst 16 percent respond increased income/profit and 49 percent answer able to care for my family. In Kenya, as many as 31 percent respond the "money being good" and 78 percent respond that the main benefit of their current job is financial benefits/income.

16 Work-related benefits include, for instance, a more secure job contract, higher or more stable income, enhanced information that helps to earn more in the job, safety, better information about alternative job offers, access to services, etc. Those workers that report loans as the main association benefit also report receiving bereavement payment. Important also to note that what workers report as the main benefit of association membership is most often not the sole benefit, as the majority of associations have multiples purposes/offer a range of services.

17 Note that the access to formal health (and pension) insurance component included in the category of social cushioning represents a rather small share of 3 percent across both countries (slightly higher for Kenya). If workers self-select into associations to gain access to for instance health insurance, then the correlation between association 
membership and official insurance schemes would be biased. Thus, for the purpose of the forthcoming analysis, it is reassuring that workers do not appear to select into associations with the purpose of gaining access to official social security schemes.

18 As with Table 3.1, the random sample equivalent is presented in Appendix A Table A2, showing that the share of SACCO members is higher whilst the worker association representation is lower, especially in Kenya. Correspondingly, the benefit types show that the incidence of loans is higher in the random sample, whereas the workrelated measure is lower. This difference is the result of the purpose-based sampling of 25 percent of workers allowing for a broader representation of different types of associations, even if the random landscape looks different.

19 Further analysis using multinomial regressions to examine the challenges that informal workers face and the key benefits they receive from their associations reveal that both challenges and benefits are quite sector and country-specific and also vary substantially by worker-types. Interestingly, however, neither challenges nor benefits differ much by gender, income, education, or age of the workers.

20 Nevertheless, 23 percent of the members are construction workers, which although a lower share than the other two sectors seems to be a rise compared with Mitullah and Wachira (2003) which in the case of Nairobi found that most construction workers did not belong to any association.

21 The difference in wages between members and non-members is statistically significant in the case of Kenya as revealed when performing t-tests by membership status split by country location, whereas, in Tanzania, the difference is not statistically significant (results not reported).

22 Reassuringly, no significant differences emerge when health insurance coverage is used instead of social protection enrolment.

23 When health insurance coverage is used as the outcome instead of SI, the results remain qualitatively very similar.

24 As recalled from Table 3.4, workers in formal SI enrolment have significantly higher earnings; yet, Table 3.5 shows that earnings do not seem to be a determinant of social security participation, when other factors are taken into account.

25 Where workers have classified that the main benefit is receiving loans, this could represent either a sacco/vicoba/chama-type association or a work-related association, but the defining characteristics is that the association provides loans.

26 The fact that the work-related and voice and representation-type associations do not show any statistical significance in terms of enabling SI access for their members does not exclude the possibility that these association types provide important social protection measures and act as potential mechanisms for workers to voice concern. For instance, in Tanzania, 43 percent of association members have contacted their associations on issues related to representation, and 40 percent of workers say that this helped resolve the issue. In Kenya, 30 percent of workers have made contact on issues related to representation, and out of those, 30 percent say that it helped resolve the issue.

27 I include age squared to allow for a diminishing marginal effect regarding the earnings returns to experience.

28 I also note that the gender pay gap is substantially higher in Tanzania (results not reported).

\section{References}

Bjerge, B., Torm, N. \& Trifković, N. (2021) Can training close the gender wage gap? Evidence from Vietnamese SMEs. Oxford Development Studies. 49 (2), 119-132.

Chen, M.A. (2005) Rethinking the informal economy: Linkages with the formal economy and the formal regulatory environment. Research Paper 2005/010. Helsinki, UNU-WIDER. 


\section{Nina Torm}

Devereux, S. \& Sabates-Wheeler, R. (2004) Transformative social protection. IDS Working Paper 232. Brighton, Institute of Development Studies.

Hickey, S. \& Seekings, J. (2017) The global politics of social protection. WIDER Working Paper 2017/115. Helsinki, UNU-WIDER.

ILO (2002) Report VI, Decent work and the informal economy, Sixth item on the agenda. In: International Labour Organization. International Labour Conference 90th Session. Geneva, International Labour Office.

Jacob, T. \& Pedersen, R.H. (2018a) Social protection in an electorally competitive environment (1): The politics of productive social safety nets (PSSN) in Tanzania: ESID Working Paper 109. Manchester, UK, The Effective States and Inclusive Development (ESID) Research Centre.

Jacob, T. \& Pedersen, R.H. (2018b) Social protection in an electorally competitive environment (2): The politics of health insurance in Tanzania: ESID Working Paper 110. Manchester, UK, The Effective States and Inclusive Development (ESID) Research Centre.

KSPSR (2017) Kenya social protection sector review 2017. Ministry of Labour and Social Protection, State Department for Social Protection. Nairobi, Kenya.

Kumar, S. \& Singh, A.K. (2018) Securing, leveraging and sustaining power for street vendors in India. Global Labour Journal. 9 (2), 135-149.

NSPP (2011) Kenya national social protection policy. Ministry of Gender, Children, and Social Development, Kenya.

NSSF (2017) Presentation on 'practical perspective of the NSSF scheme' Workshop Report: Social Protection and Informal Economy International Launch Workshop (Nairobi, 2017).

Mincer, J. (1974) Schooling, experience, and earnings. National Bureau of Economic Research.

Mitullah, W.V. (2010) Informal workers in Kenya and transnational organizing: Networking and leveraging resources. In: Lindell, I. (ed.) Africa's informal workers: Collective agency, alliances and transnational organizing in urban Africa. London, Zed Publications, pp. 184-203.

Mitullah, W.V. \& Wachira, I.N. (2003) Informal labour in the construction industry in Kenya: A case study of Nairobi. Geneva, International Labour Office.

NBS (2014) Integrated labour force survey. Dar es Salaam, National Bureau of Statistics.

Rizzo, M. (2011) 'Life is war': Informal transport workers and neoliberalism in Tanzania 1998-2009. Development and Change. 42 (5), 1179-1206.

Rizzo, M. (2017) Taken for a ride: Grounding neoliberalism, precarious labour, and public transport in an African metropolis. Oxford, Oxford University Press.

Schmalz, S., Ludwig, C. \& Webster, E. (2018) The power resources approach: Developments and challenges. Global Labour Journal. 9 (2), 113-134.

Silver, B.J. (2003) Forces of labor: Workers' movements and globalization since 1870. Cambridge, Cambridge University Press.

Spooner, D. \& Mwanika, J.M. (2018) Transforming transport unions through mass organisation of informal workers: A case study of the ATGWU in Uganda. Global Labour Journal. 9 (2), 150-166.

Torm, N. (2020). Social protection and the role of informal worker associations: A cross-sector analysis of urban sites in Kenya and Tanzania. Roskilde University. CAE Working Paper Nr. 2020:3.

Wells, J. \& Jason, A. (2010) Employment relationships and organizing strategies in the informal construction sector. African Studies Quarterly. 11 (2\&3), 107-123.

Wright, E.O. (2000) Working-class power, capitalist-class interests, and class compromise. American Journal of Sociology. 105 (4), 957-1002. 